\title{
AUTHENTIC MARKETING PRAGMATIC MARKETING (COMPONENTS, FOREGROUNDS, OUTCOMES): INTERACTIONS \& CONFLICTS
}

\author{
Zohreh Ali Esmaeili \\ Anzali International Unit, Iran \\ E-mail: zohreh_esmaili23@yahoo.com \\ Bahram Kheiry \\ Azad University at Tehran Markaz Branch, Iran \\ E-mail: bahramkheiri@gmail.com \\ Farzin Farahbod \\ Azad University at Tehran Markaz Branch, Iran \\ E-mail: farzinfarahbod@yahoo.com
}

Submission: $10 / 21 / 2019$

Revision: $11 / 6 / 2019$

Accept: 11/22/2019

\section{ABSTRACT}

The age of new technology is fraught with contradictions, engagement and communications that the customer with the crisis of meaning and absurdity that stems from obedience and consumption. And in the same vein, authenticity, which Katler considers to be the most effective element in this era, in order to achieve a sustainable development and response to the psychological adventures of the customer, which he calls the human soul. Also, the efforts of brands to maintain and develop their own beliefs and philosophies have made it necessary to study the concept of authentic marketing. And, on the other hand, the study of its interaction with the pragmatic marketing, which is a response to the material needs of the client, is necessary, therefore, their consequences can be the answer to the theoretical vacuum of marketing science to solve customer's contradictions in the new paradigmatic shift. The present research is applied in terms of purpose and uses the method of qualitative research in the form of the Structural Foundation data theory. Methods of collecting data is through in-depth interviews and observing. Eventually, data were analyzed using the principles related to underlying theory (open and selective coding, continuous comparative analysis, creation of concepts and compilations). Finally, this study suggests that 
changing marketing paradigm to solve the problems of new age for authentic brand production.

Keywords: Authentic Marketing; Pragmatic Marketing; Paradigm Shift; Cultural Marketing; Authentic Brand 
DOI: 10.14807/ijmp.v11i6.1150

\section{INTRODUCTION}

In 1965, Kotler considered the transaction as a "social exchange" process in a paper that describes the concept of marketing as a social exchange process. Accordingly, the purely economic viewpoint of marketing is a mistake of proximity and it hinders the development of marketing science (HAGIGHI et al., 2013).

Also, in his book entitled the third age of marketing, Katler calls marketing as the era of value creation, and marketing managers, instead of treating people as consumers, regard them as people with the brain, heart, and soul, marketing is not a process that only marketers follow in their relationship with the consumer. Consumers also use marketing in their daily communication.

Third-age marketing sees customer as a human being, the human being has four basic elements, a body, a mind that has the ability to think and analyze independently, the heart that can feel the emotions and the spirit or philosophical center of the body, hence he considers authenticity or credibility as the most effective element of the new age in creating sustainable development (KATLER et al., 2010).

In a world full of complexity, customers are looking for companies that meet their deep needs for social, economic, and environmental justice in mission, vision and values. Not only do they seek to meet their functional and emotional needs in the products and services they choose, but also meeting spiritual needs is important for them. Third-age marketing moves the concept of marketing to ideals, values, and spiritualties, and believes that consumers are perfect people and their needs and expectations should not be ignored. Therefore, third-age marketing combines "emotional" marketing with "spiritual" marketing (KOTLER; COLLEAGUES, 2010).

In the book Evolution and Evaluation, Jagdish Sheth et al. explains the evolution of marketing concepts in two aspects of philosophy of science and the universe (2004). Cultural marketing is the second most important marketing element of the third age. Third-age marketing is an approach that does not overlook the concerns and interests of global citizens. Marketers of the third age must understand the problems of the community that are related to their business (KATLER et al., 2010).

The concept of community interest is considered in the new definition of the 2008 American Marketing Association. According to this definition, marketing is a set of activities 


\section{INDEPENDENT JOURNAL OF MANAGEMENT \& PRODUCTION (IJM\&P)}

http://www.ijmp.jor.br

v. 11, n. 6, September - October 2020

ISSN: 2236-269X

DOI: 10.14807/ijmp.v11i6.1150

and processes for establishing communication, supply and exchange of proposals that are valued for consumers, clients, partners and society (2008).

From critical dialogue on marketing, marketing is an ideology as a software for implementation and capitalist productivity, the most important device for managing and shaping cultural production and processes of transformation in this regard (PAYATYA, 2013), and a tool for political diffusion (BOUTANG, 2011).

On the other hand, pragmatism is a paradigm and a method for solving or evaluating rational issues, as well as a theory about the types of identifications we are prone to studying and acquiring. This school, called pragmatism, or the principle of action, considers a proposition as truth that have practical utility and in other words, the truth is the meaning that makes the mind to achieve more and better practical results (HATAMINEJAD; FARZANKRUD, 2013).

Pragmatism is a revolutionary against idealism and purely rational explorations that have no benefits for humans, while this philosophy is a method of solving intellectual problems and a kind of revolutionary dialectic, which can be very beneficial in the progress of human evolution (HAKIMI, 1984). Pragmatic marketing is a product development process, based on experience planning adaptability, re-testing and re-adaptability as long as the final result, both theoretically and practically, has evolved as a better product.

The first step in pragmatic marketing is to discover what the customer wants to buy. Pragmatic marketing involves understanding market problems by conducting interviews with customers as well as potential customers to understand their critical issues. This measure is also important to understand why potential customers and clients have evaluated a product in a particular way, and also includes an assessment of the strengths and weaknesses of competition (VAMICHA, 2018).

Theories are an important tool for pragmatists to guide their decisions, and market valuation and theoretical critique of pragmatists increase the validity of marketing theories. The spirit can be found, pragmatic marketing also relates the real facts of business in relation to ethics from business practices, creates a critical approach between philosophers and society, and the ethical attitudes of business for human flourishing in the precise and continuous pragmatism (ANDERSEN, 1999).

The warning of Iranian economists to the crisis of value created in Iranian consumer's desire to constantly buy foreign products, which includes types of products from low-level 


\section{INDEPENDENT JOURNAL OF MANAGEMENT \& PRODUCTION (IJM\&P)}

http://www.ijmp.jor.br

v. 11, n. 6, September - October 2020

ISSN: 2236-269X

DOI: 10.14807/ijmp.v11i6.1150

needs to social situations, makes it necessary to redefine and the creation of a new way of producing value in Iranian society (MALJOU, 2017). Authentic marketing is a strategy for organizations to validate their business goals in a credible action, (ACKER, 2014).

It seeks to increase brand's desirable characteristics, which requires sustainability of capital resources in developing brand value and extending this behavior over time (MORHART et al., 2015). Because the symbolic source is helping the consumer in his definition and the meaning of his life, so in this strong bond, the brand gains trust and growth (EGGERS et al., 2012).

Various meanings and types of authenticity (e.g. as attribute of objects, an existential experience of 'true self') are in addition imposed by different research traditions (REISINGER; STEINER, 2006). It is thus no surprise that Reisinger and Steiner (2006) conclude that the different views on (object) authenticity are conflicting and irreconcilable. Tomaz Kolar and Vesna Zabkar (2010), focused both types of authenticity in Truism industry. They acknowledge the distinction between object-based authenticity and existential authenticity, as they pertain to different entities (i.e. object/offerings and tourist existence/self) that should be considered separately, but they didn't show according to contemporary field conditions. which paradigm is necessary for engaging customers and solving epistemic crisis to produce sustainable value.

This study, with the definition of authentic marketing, seeks to remove the corner of this theoretical vacuum of value interactions and authentic it in practice. In his book thirdcentury marketing, Flip Katler emphasizes the importance of creating sustainable credit values and proposes the $3 \mathrm{i}$ model for producing sustainable value based on three principles of nature, integrity and distinction (validity and authenticity). But what is so remarkable in existing studies is the lack of field research to build a model and reliance on scholars to examine existing literature.

Therefore, the dimensions of authentic value as a framework for achieving the goal of sustainable growth in today's world, and its predecessors and consequences, and its interactions and oppositions with the authentically of the operation, have deficiencies that researchers themselves find in this field. Regarding the persistence of authentic and value-driven encounter in society and its biased application in favor of a particular opinion, the need to redefine the concept and subject matter as well as methods and tools according to contemporary field conditions is an inevitable necessity.

\subsection{Review of Literature}


INDEPENDENT JOURNAL OF MANAGEMENT \& PRODUCTION (IJM\&P)

http://www.ijmp.jor.br

v. 11, n. 6, September - October 2020

ISSN: 2236-269X

DOI: 10.14807/ijmp.v11i6.1150

According to the Oxford Dictionary, Authentic means " original and without a copy; genuine". In marketing, it means the same, it means creating a dialogue between your brand and your audiences that are natural and real. It's not necessarily true or ethical, as many people believe, is a kind of strategy that you can use to build deeper communities based on trust and empathy. Authenticity is essential for a new business (GILMORE; PINE, 2007), which uses the Latin word 'authenticus' and the Greek word 'authentikos' meaning 'acceptability, credibility, trust, not imaginary, false, or imitation, and in accordance with the principle.' (CAPPANNELLI, 2004) This is what you share. The credibility is to believe in your character, writer, or company (PATEL, 2016).

The brand's position alone is not enough. Completion of this process requires a distinction between authenticity for the human soul, which creates a sustainable value in the economy, society and environment, hence it is the only elements that affect third-age of honesty, authenticity, credibility marketing (KATLER, 2010).

A new concept of consumer brand credibility suggests that a credible brand is trustworthy, cares for its consumers, helps them define and build their identity, and represents continuity from the past to the future. (MURHART et al., 2015). Because their credible brands are a meaningful source of identity building, they must have credible behaviors. (BORLAND; FARLEY, 2010).

Valid brands are real, reliable, and meaningful (GILMOURE; PINE, 2007) Credit is increasingly recognized as a desirable brand attribute. Brand originality refers to a brand that is honest and realistic (ALEXANDRE, 2009; GILMOURE; PINE, 2007), distinguishes its credible brand through intimacy, commitment to quality and relevance to its heritage (BORLAND, 2006; NEAPOLI et al., 2014).

Valid brands have the ability to communicate with consumers at the emotional level through their quality symbols (ROSSKAA, 2007; MURHART et al., 2015). A new concept of credible brand indicates that a credible branding brand for consumers is helping them define and build their identity and represent continuity from the past to the future (RAT et al., 2015). Valid consumption is suitable for a wide range of consumer objects and activities that have the potential to create meaning (BORLAND, 2005).

Significant investments have been made in developing brand values and consistently favorable behavior over time (MURHART et al., 2015). Since valid brands are defined as symbolic resources (BORLAND; FARLEY, 2015) that help consumers define the meaning of 
INDEPENDENT JOURNAL OF MANAGEMENT \& PRODUCTION (IJM\&P)

http://www.ijmp.jor.br

v. 11, n. 6, September - October 2020

ISSN: 2236-269X

DOI: 10.14807/ijmp.v11i6.1150

their lives (LEE et al., 2006), they benefit from them and have a competitive advantage in terms of building strong relationships with consumer brand (BORLAND, 2006; MURHART et al., 2015), the impact of brand originality on the emotional affiliation of a consumer is different in a variety of situations (e.g. MAURARD et al., 2015).

Despite high level of agreement in the correct relationship with consumer behavior and its relation to truth, integrity and transmission of meaning to consumers, literature is characterized by a diverse and divided approach, and the focus of attention is to be considered in an attempt to accept a generally accepted notion. Given this view, Burrland and Farley (2010) argu that the nature of credit in consumption is debatable. "This challenge extends to the field of brand, while there is still a lack of a general definition of credit (FELICITAS; MURHART, 2014).

"Creating authenticity in marketing" is partly regarded as a paradox, "all human economic organizations are cognitively fake-in the sense that they are not credible inside-and, at the same time, the output can be in terms of phenomenologically real, that is, it is perceived as valid by the person who buys it "( ECKEL, 2015). The marketing and consumer research literature acknowledges that attempts to consume credible are due to the loss of traditional sources of meaning and personal identity linked to postmodernity (ARNOLD; PRICE, 2000; BORLAND; FREELY, 2010, THOMSON, 2006).

Credibility, as an idea expressed in philosophy and literature, was created in Europe in the 18th century. But moreover, there were a number of widespread and interwoven developments, all of which were related to modernity, which is a complete expression: the slow recession of belief in the cosmic order with the fixed and undeniable social roles, the idea of coping with the individual's autonomy (with his claim for inner depth, dignity, and selfresponsible liberty), the emergence of capitalism, labor, wage and authority of science and enlightenment demand rationality.

The key point is that these aspects of modernity were prerequisites for stimulating ideal credibility. In other words, this originality was a product and a reaction against modern life. In this regard, credibility is like Orthodox religion. Jean-Jacques Rousseau, a philosopher and novelist of the eighteenth century, pointed out each of the original elements: (1) the concept is that we all have a unique and original principle (2) that exists within us (3) must be discovered by ourselves (often in terms of nature), and (4) what we want to express, even in (5) the negation of social agreements (DAVIS, 2017), for example, Halt (2004) ) explained that 
DOI: 10.14807/ijmp.v11i6.1150

Adorno "sees the danger of this term in accepting it by those who continue to believe it and experience an imaginary reality that they share through the power of communication."

Cultural materialism sees economics as the foundation of social life and culture on its foundation, hence the various ideological currents of capitalism, Marxism, fascism of ideology are as a program for gaining power and capital, and attempted to promote public opinion in order to consume more of its products and increase the mass market by promoting products in the cultural space and reducing the dynamism of culture to ideology (ANDERSON, 1976).

Economic forces were the basis of society in terms of Marx and Engels, and the relations of production in which culture and ideology were built to help secure the domination of the ruling social groups. The "infrastructure / superstructure" model considers the economy as the foundation or base of society, and culture, law, politics, and other forms of life are understood as "superstructures" that grow beyond it, and serve to reproduce economic base. The analysis of mode of production capitalism, current economic developments and political struggles, and inequalities of global market and modern societies are now known as the theorists of "globalization" and "modernity".

Anderson (1976) interpreted that economic and political analysis of cultural theory was a sign of defeat of Western Marxism after collapse of 1920s revolutionary movements of fascism. The combination of "domination", or the force of "hegemony", and satisfaction, are defined as "intellectual and moral leadership." Thus, social orders arise and reproduce. In fact, globalization is fraught with contradiction. In this connection, Charles of India believes that people should not attempt to resolve this conflict, but must manage it (1994).

Different authors defined authentic marketing in different manner, but according to contemporary field conditional such as "globalization", "new age technology", "participation", "communication rationality", and Intervener conditions such as "industry culture" , "concept contradictory" and "cultural Marxism", similar definition according to paradigm shift for solving epistemic crisis to produce sustainable value is necessary, Common to these studies is the idea that perceived authenticity is a consequence/output of their experience with a certain place (culture, museum, site).

The relevant literature, on the other hand, implies that authenticity can also be considered as an antecedent/input of tourist behavior, as it is often considered as an important driver, value, motive or interest (KOLAR; ZABKAR,2010). Tourists experiencing various 
INDEPENDENT JOURNAL OF MANAGEMENT \& PRODUCTION (IJM\&P)

http://www.ijmp.jor.br

v. 11, n. 6, September - October 2020

ISSN: 2236-269X

DOI: 10.14807/ijmp.v11i6.1150

levels of satisfaction or dissatisfaction after experiencing each services in accordance with the extent to consumer expectations are met or exceeded(AZHAR et al, 2019).

Also, Katler (2010), in the book third-age marketing These three major forces have taken consumers to "cooperation," "culture," and "spirituality." Understanding these developments can lead to a better understanding of third-age marketing as a collaborative, cultural and spiritual marketing (KATLER, 2010).

Businesses that respond to their mental needs. The future value proposition of marketing is the supply of spirituality. The value-creating business model is the new fundamental tool for third-age marketing. Findings by Melinda Davies on the human interest project confirm this. He found that psychosocial benefits are the most urgent needs of consumers today, and maybe the ultimate margin of discretion that companies can create. (DAVIS, 2002).

How can companies create value in their business models? As a response to this fundamental question, Richard Barrett believes companies can look at levels of spirituality in their business models, like humans. He found that human level of spiritual motivation can be considered in the mission, vision and value of companies (BARRETT, 1998).

The configuration and management of a supply chain in a global context compose important elements that enable the achievement of higher performance which drive the companies to achieve a proper level of competitiveness (BORGES, 2015). Human being is a social being and the means of communication between humans is language, which in the process of socialization causes the transfer of human heritage and knowledge from one generation to another.

Human interaction is symbolic, and humans communicate with each other through symbols and signs. According to Habermas, symbols are the means of temporary domination to gain domination over nature, and the fundamental role of benefits and interests derives from recognition of duality of the fact that human beings are instrumental and, at the same time, an intelligent inventor.

Human interaction makes people communicate with each other through symbols. But the same language is also a social product. These discoveries and what describes the social world and our actions are not individual products, but are a social product. A language that reflects representations is not an impartial and neutral language, and is always seeking convincing reasons to justify its irrational actions and behavior (TAVASOLI, 2005). 
INDEPENDENT JOURNAL OF MANAGEMENT \& PRODUCTION (IJM\&P)

http://www.ijmp.jor.br

v. 11, n. 6, September - October 2020

ISSN: $2236-269 X$

DOI: $10.14807 /$ ijmp.v11i6.1150

This interest in "interconnectivity" requires that we, by choosing interpretive methods, understand human behavior. Human science should not be a model of natural science, but should find ways to understand and interpret human communication. These paths must be "Hermeneutics "or" Interpretational "(more like a conversation) (GHOLIPOUR, 2006). increase brand awareness it is necessary: to increase interaction with your brand, build positive brand associations, increase brand loyalty by linking it with the target audience, and motivate customers to get acquainted with your brand and associated products (ISORAITE, 2016).

Society, market and search for a development in an orderly manner, encourage businesses to introduce sustainable practices in their systems, in order to attend the environmental needs(Slvador and et al, 2014).Building a communicative bio-society in all the fields of action within which there are three flowing reproduction of symbolic production: cultural expansion, social integration and socialization. The "communicative infrastructure" of the rationalized world of life consists of an action-oriented understanding that creates a rational context for "transfer of credibility" through three mentioned flows.

This transfer of rational impulse (in the sense of communication) can only be taken if action-oriented actors are inclined towards other consequences and credibility claims. While an action geared to money and power wants to objectify the tendency toward success. Colonization of the world of life is reflected more clearly with the emergence of major imbalances in the re-production of material, leading to system degradation. Flow of degradation, willingly or unwillingly, will lead to crisis or illness threatens identity, which is experienced "individually" (WHITE, 1990).

The common creation is the term used by Prahalad for the first time to describe the new approach to innovation. Prahalad \& Krishnan, in the book New Age of Innovation, saw new ways of creating products and experiences in engagement with companies, consumers, suppliers and distribution channels partners that are linked through innovation network (PRAHALAD; KRISHNAN, 2007). The experience of the product itself is not the product experience, but the sum of experiences of each consumer that gives the highest value to product. When any consumer experiences a product, they customize that experience according to their unique needs and desires (KATLER, 2010).

Companies that want to focus on this new trend should pay attention to these needs and help consumers connect with each other in the community. Gadin stated that business success requires the support of these communities. According to Fournier and Lee, consumers 
INDEPENDENT JOURNAL OF MANAGEMENT \& PRODUCTION (IJM\&P)

http://www.ijmp.jor.br

v. 11, n. 6, September - October 2020

ISSN: 2236-269X

DOI: 10.14807/ijmp.v11i6.1150

can be organized in coalition communities around the leader, the web or the idea (FOURNIER; LEE, 2009).

In Colombia's encyclopedia, hermeneutics has been interpreted into the theory and practice of interpretation. In translation into Persian, hermeneutics means interpretation and compliance, which interpretation is of course a more precise translation, because it means something that lies behind everything, and this is what is considered in hermeneutics, the word hermeneutics originally derives from the word Hermes.

The key to understanding of hermeneutics is language, and hermeneutics seeks to understand social and political behavior through in-depth examination of nature of human imagery, intellectual processes, and its cognitions. Hermeneutics seeks to ascertain the attitudes and intentions of the creator of a work, or at least approach it, and this is what Foucault interprets it as breaking the iron cage of the mind (MANOCHEHRI, 2007).

It is also possible to understand the meaning of interpretive approach through recognition of conceptual approach and phenomenology that are considered as interpretative approaches. The conceptual method of interpretive approach is an attempt to reveal meaning, there is no real starting point for achieving meaning, since each understanding contains the previous understanding (hermeneutic period) (SHIRODI, 2009).

Habermas' areas of interest include critique of classical sociology from workshops to new ideas in the field of social philosophy such as the theory of "general pragmatism" and attention to civil society and the public sphere, as well as the subject of systematic presentation of intellectual concepts (the new paradigm of analysis) are scattered in humanities and it is difficult to address them. However, his attention to modernity should never be considered as insignificant. But what is important for Habermas is the recognition of nature of "social action" as the beginning of study of human society (AKBARI, 2006).

Pragmatism calls philosophy for accountability. To solve problems and deal with issues related to social consequences, the business ethics that is underway is the exact attempt of philosophy to deal with specific issues and practices. The business world is taking place. The commercial culture is viewed by philosophers as critics with a practical attitude (RALPH, 2007).

\subsection{Experimental background}

Authentic Marketing or Authenticity or Credit from Katler's View in the Third Age Marketing is the main elements of marketing in this era which leads to the production of 
DOI: 10.14807/ijmp.v11i6.1150

sustainable companies. Katler examines the presentation of value of the third age in $3 \mathrm{i}$ with three main elements, and finding a sustainable value requires presentation of a distinction in DNA of brand personality, which gives it an authenticity and credit. Third-age marketing should be redefined as three sides of triangle, including trademark, placement and differentiation.

This model has three components of integrity, nature and mental image, an alleged placement that warns consumer about inauthentic brand. The distinction between brand DNA and reflection of integrity and synergy becomes a mental image; only the complete triangle is complete in third-age marketing (KATLER, 2010). The model has been expanded without a field study.

Moulard and colleagues in 2015 conducted a study entitled "How can a human brand be credible?" They conducted the well-known credit history they are affected by two variables of scarcity and stability by mentioning their dimensions. Qualitative and survey research in a 248-member society has examined the growing trend of marketing research as a credible understanding of a wide range of market proposals.

In a research entitled Pragmatic Perspectives on International Marketing Training, Jim Bell Stephen Brown (1990) strengthens science and practice in an interactive approach between academia and industry. Academic knowledge is on the rise and institutions need to be closer to the industry and more pro-active pursuit of an interactive market-based approach to education, in addition, there is a positive relationship between industry and university to help strengthen the link with government. Long-term goals of a vibrant economy are complementary to the identification of their individual contributions, and these actors can create a synergy and a supportive engagement that consists of strengths of each other and improve the validity of action.

In a study titled Converting Massive Data to Pragmatism in Target Marketing, Miao He et.al (2013) examines the enhancement of practical insights through data mining. In this model, product insight, customer insight, and geographic perspective of three dimensions and other dimensions are considered as data analysis, and it concludes that our insights are gained from massive data analysis.

In a research entitled "The Two-Way Effect of Information Processes on Practicing and Consumer Experience on Brand Acceptance", Schmidt et al., (2017) maintain that modern management of consumer experience, in the modern digital era, has a profound knowledge of 
DOI: 10.14807/ijmp.v11i6.1150

its main elements and consequences. Social psychology and neural economics argue that most of the mental processes of the implicit human being, that is, from nature, are hidden in the subconscious mind of man. According to this definition, this research focuses on explicit and implicit impact of user's experience on brand ethics, and a conceptual model of integrating explicit informational processes of consumer experience of enjoyment and pragmatism.

\section{METHOD}

Since the present study seeks generating and developing theory from qualitative data, it is based on principles of underlying theory. It incorporates systematic techniques and analytical procedures that enable a researcher to develop a fundamental theory and to meet the criteria for doing good science (POUR, 2013, p. 315).

In fact, we are allowed to look for the underlying theory when it is felt in the scientific tradition of the empty space of a theory, or has been investigated, but still there are still ambiguities, and our theatrical specification needs to be completed (FERASATKHAH, 2016, p. 77). The present study also sought to identify the dimensions and expand concept of interaction and opposition between authentic marketing and pragmatic marketing, which Katler (2010) and Mauwi et al. (2013) first put forward, and emphasized the need for field research to develop this concept.

Therefore, the present research, which seeks to complete the theoretical Atlas on the authentic and pragmatic marketing of qualitative data, is based on field theory. The present research can also be considered based on the systematic approach of underlying theory, according to Strauss and his colleague Corbin (1987). The research community is Iranian consumers. For sampling, we must should look at the research in the zero stage of research whether individuals who carry information and experiences lived and thought here are multidisciplinary, multi-class and, in the framework of it, refer to examples we know to have the necessary information and experience (FERASATKHAH, 2016, p. 137).

Hence, on the one hand, since the subject matter of research was to determine dimensions of authentic and pragmatic marketing, and demanded full understanding of categories of consumption and experience of thought, and on the other hand, due to interdisciplinary nature of the concept of verbal values and related concepts with it such as cultural marketing, spiritual marketing in today's world has been referred to researchers and university professors in business management, philosophy, economics, sociology and 
DOI: 10.14807/ijmp.v11i6.1150

psychology, which is about expressing their own experiences with respect to awareness and acquaintance with theoretical foundations of the topic of research that have more oversight.

Therefore, the targeted sampling process has been used and the information gathering in each domain has continued to reach the theoretical saturation. The data collection tool was an in-depth interview and, in the end, 14 interviews were conducted. Also, since addressing these concepts in the past decade has been the concern of researchers in different fields and this effect is visible in their research, their lectures and trainings have also been used to gather information, of which 22 are number one, on the other hand, since their social roles in sustaining the role of creating credit values are continuous, 12 in-depth interviews were conducted with them. Their distribution are given in Table 1 and 2:

Table 1: Interviews and observation by researchers

\begin{tabular}{|c|c|c|}
\hline Field of study & $\begin{array}{c}\text { Number of } \\
\text { interviews }\end{array}$ & $\begin{array}{c}\text { Number of } \\
\text { observations }\end{array}$ \\
\hline $\begin{array}{c}\text { Business Administration } \\
\text { Marketing }\end{array}$ & 5 & - \\
\hline Philosophy & 4 & 10 \\
\hline Economy & - & 12 \\
\hline Philosophy of Art & 1 & - \\
\hline Sociology & 2 & - \\
\hline Psychology & 3 & - \\
\hline
\end{tabular}

Table 2: Interviews by Social roles

\begin{tabular}{|c|c|}
\hline Social role & Number of interviews \\
\hline Family & 8 \\
\hline Reference group & 2 \\
\hline Sub-culture & 2 \\
\hline
\end{tabular}

\subsection{Steps of Coding:}

Open Coding: Open Coding is the first step in the process of data interpretation. In this context, meaningful data can be a small sentence, or a part of a clause, or one or more clauses of the entire textual content (FERASATKHAH, 2016, p. 153). Sample quotations and open encoding is presented in Table 3. 
INDEPENDENT JOURNAL OF MANAGEMENT \& PRODUCTION (IJM\&P)

http://www.ijmp.jor.br

v. 11, n. 6, September - October 2020

ISSN: 2236-269X

DOI: 10.14807/ijmp.v11i6.1150

Table 3: Sample quotations and open encoding

Sample quotations

Because we have limited resources, sometimes there is an urgent need for consuming and delivering products, such as lack of technology or money or attitudes. Side effect s We do not have medicine because we do not have technology

We lack resources. In our marketing is not a long-term view, it's aggressive. First, it's pragmatic, but its reform is idealistic, we begin with pragmatics with low resources, where we need to make reforms.

Here we can talk about social marketing seeking to change behavior in society.

In marketing, for the elimination of short and short term brands, there are re-branding, we start pragmatically with low resources, where we need to reform, this view that we can firstly be pragmatic and then have the reforms

A new word for solving anthropological issues. Customer engagement is a feeling of customer belonging, modeling and function of different factors. For example, delivering a product to different classes based on our customer's ability is not the best, but based on the customer's requirements, which creates loyalty to behavior.

The big organizations of the world acquire communication tools and do not let public views go ahead. The brand owner must criticize himself socially who takes his legitimacy from social marketing.

We need to combine the pragmatic and idealistic view. Pragmatics means pragmatism and problem solving. We have two points of view. We have an ideal view, and we have a best practice view that is short-term and pragmatic to fit into society to take it into the best fit.

With regard to third-generation marketing, I believe that in the competitive markets, in view of the many different business organizations, it should seek to create unique experiences.

The brand credibility of the organization's feedback is from its stakeholders; in other words, business organizations rely on views of stakeholders of organization to promise their audience, which can lead to an increase in brand credibility of organization.

Marketing can have a long-term and Short term perspective.in this perspective, long-term and human-centered look is needed; shifting the marketing paradigm is a necessity.

\section{Open coding}

Resource limitations

Changing society behavior

Rebranding Approach to Solve Ethical Issues

customer engagement and attitude loyalty

Social criticism from the sources of public acceptance

Problem-oriented

Creating unique experiences

Assessment of compliance with obligations

Paradigm shift

Axial encoding: In the axis coding, the source code is derived from recoded coding step, and these communications are verified through data; in the pivotal coding, the researcher compares the categories and concepts derived from the open coding step and combines, integrates, reduce and summarize them (FERASATKHAH, 2016, p. 169). At this point, codes containing the same meanings are placed next to each other under a larger abstract concept that includes all of them and makes the categories. Therefore, in the present study, the identified concepts in the open coding step were classified in 6 block categories, the first and second stages are described in the research findings section. 
DOI: 10.14807/ijmp.v11i6.1150

- Selective encoding: After the axial encoding, the final encoding stage is selective encoding. At this stage, the categories used are theoretically saturated, and the researcher must choose the nuclear category or determine and construct a new category (MOHAMMADPOUR, 2013, p. 340).

\subsection{Findings}

In this research, the results of the data analysis led to the identification of 1200 concepts. Considering the accumulation of categories, the multilevel classification method and the formation of a cluster for the analysis have been used, which eventually were categorized into 6 block categories. Each block consists of clusters or clusters of a category in which some clusters have up to 3 levels of semantic opening. Because of the large volume of findings, some of which are presented as examples in the table and the rest are interpreted explicitly in the following coding steps:

\subsubsection{Causal conditions}

The main causes and reasons of which the phenomenon of exploration (the main category) derives from them (FERASATKHAH, 2016, p. 100). The categorical block of causal conditions includes two clusters of categorical marketing and pragmatic marketing. Sample of blocks of the category of causal conditions is presented in Table 4 .

Table 4: Sample of blocks of the category of causal conditions

\begin{tabular}{|c|c|c|c|}
\hline Concept & first level category & second level category & $\begin{array}{l}\text { Category } \\
\text { cluster }\end{array}$ \\
\hline Metaphysical ontology & \multirow[t]{2}{*}{ Ontology } & \multirow[t]{8}{*}{$\begin{array}{c}\text { Authentic marketing } \\
\text { paradigm }\end{array}$} & \multirow{10}{*}{$\begin{array}{l}\text { Authentic } \\
\text { marketing }\end{array}$} \\
\hline Transcendental truth & & & \\
\hline General hermeneutics & \multirow[t]{4}{*}{ Epistemology } & & \\
\hline Phenomenology & & & \\
\hline hermeneutics & & & \\
\hline German idealism & & & \\
\hline $\begin{array}{l}\text { Discovering meaning } \\
\text { behind everything }\end{array}$ & \multirow[t]{2}{*}{ Methodology } & & \\
\hline $\begin{array}{c}\text { Interpretation of the deep } \\
\text { interpretation of } \\
\text { phenomena through } \\
\text { language }\end{array}$ & & & \\
\hline $\begin{array}{l}\text { Creating different concepts } \\
\text { from product }\end{array}$ & \multirow[t]{2}{*}{ Product boost } & \multirow[t]{2}{*}{ Mixed authentic marketing } & \\
\hline $\begin{array}{l}\text { Customer involvement in } \\
\text { product creation }\end{array}$ & & & \\
\hline
\end{tabular}


ISSN: 2236-269X

DOI: 10.14807/ijmp.v11i6.1150

\begin{tabular}{|c|c|c|}
\hline $\begin{array}{l}\text { Promoting different life } \\
\text { styles }\end{array}$ & & \\
\hline $\begin{array}{c}\text { Symbolic value replaces } \\
\text { exchange value }\end{array}$ & \multirow[t]{3}{*}{$\begin{array}{l}\text { Contradiction in } \\
\text { price }\end{array}$} & \\
\hline $\begin{array}{l}\text { The thrill of discovering a } \\
\text { new phenomenon based on } \\
\text { expected value }\end{array}$ & & \\
\hline online distribution & & \\
\hline More customer interaction & \multirow[t]{2}{*}{$\begin{array}{c}\text { Presence at the place } \\
\text { of sale }\end{array}$} & \\
\hline More customer interaction & & \\
\hline $\begin{array}{l}\text { Contributing to socio- } \\
\text { cultural transformation }\end{array}$ & $\begin{array}{c}\text { Customer } \\
\text { engagement in } \\
\text { product promotion }\end{array}$ & \\
\hline social responsibility & \multirow[t]{3}{*}{ social marketing } & \multirow[t]{12}{*}{ Building a social platform } \\
\hline Changing society behavior & & \\
\hline $\begin{array}{c}\text { Customization and } \\
\text { personalization }\end{array}$ & & \\
\hline $\begin{array}{l}\text { Finding safe space for high } \\
\text { level discourse }\end{array}$ & $\begin{array}{l}\text { Exchange of } \\
\text { information }\end{array}$ & \\
\hline Deepening the debate & \multirow[t]{3}{*}{$\begin{array}{c}\text { Creating a new } \\
\text { social arrangement }\end{array}$} & \\
\hline $\begin{array}{l}\text { Using creativity of } \\
\text { customer }\end{array}$ & & \\
\hline Strengthening social media & & \\
\hline $\begin{array}{c}\text { Strengthening } \\
\text { communications } \\
\end{array}$ & Online platform & \\
\hline Tolerance of common work & \multirow[t]{2}{*}{$\begin{array}{l}\text { Interactions } \\
\text { tolerance }\end{array}$} & \\
\hline e-WOM & & \\
\hline UGC & \multirow[b]{2}{*}{$\begin{array}{l}\text { Easier content } \\
\text { sharing }\end{array}$} & \\
\hline $\begin{array}{l}\text { Reflection of non-material } \\
\text { relationships }\end{array}$ & & \\
\hline Liberating thoughts & \multirow[t]{5}{*}{ Ideal values } & \multirow[t]{10}{*}{ Authentic values } \\
\hline Human nature & & \\
\hline $\begin{array}{c}\text { Reflection of human and } \\
\text { moral values }\end{array}$ & & \\
\hline $\begin{array}{l}\text { Orientation towards } \\
\text { transcendental goals }\end{array}$ & & \\
\hline $\begin{array}{l}\text { Increasing production } \\
\text { values }\end{array}$ & & \\
\hline $\begin{array}{c}\text { Transcendence of human } \\
\text { civilization }\end{array}$ & \multirow[t]{2}{*}{ Developed countries } & \\
\hline $\begin{array}{l}\text { Much interest in solving } \\
\text { problems }\end{array}$ & & \\
\hline Low Income Markets & \multirow[t]{2}{*}{ Poor countries } & \\
\hline $\begin{array}{c}\text { Psychological Advantage } \\
\text { of Main Requirement }\end{array}$ & & \\
\hline $\begin{array}{l}\text { In search of social- } \\
\text { economic-environmental } \\
\text { justice }\end{array}$ & $\begin{array}{l}\text { Inverted Maslow } \\
\text { Pyramid }\end{array}$ & \\
\hline
\end{tabular}


ISSN: 2236-269X

DOI: 10.14807/ijmp.v11i6.1150

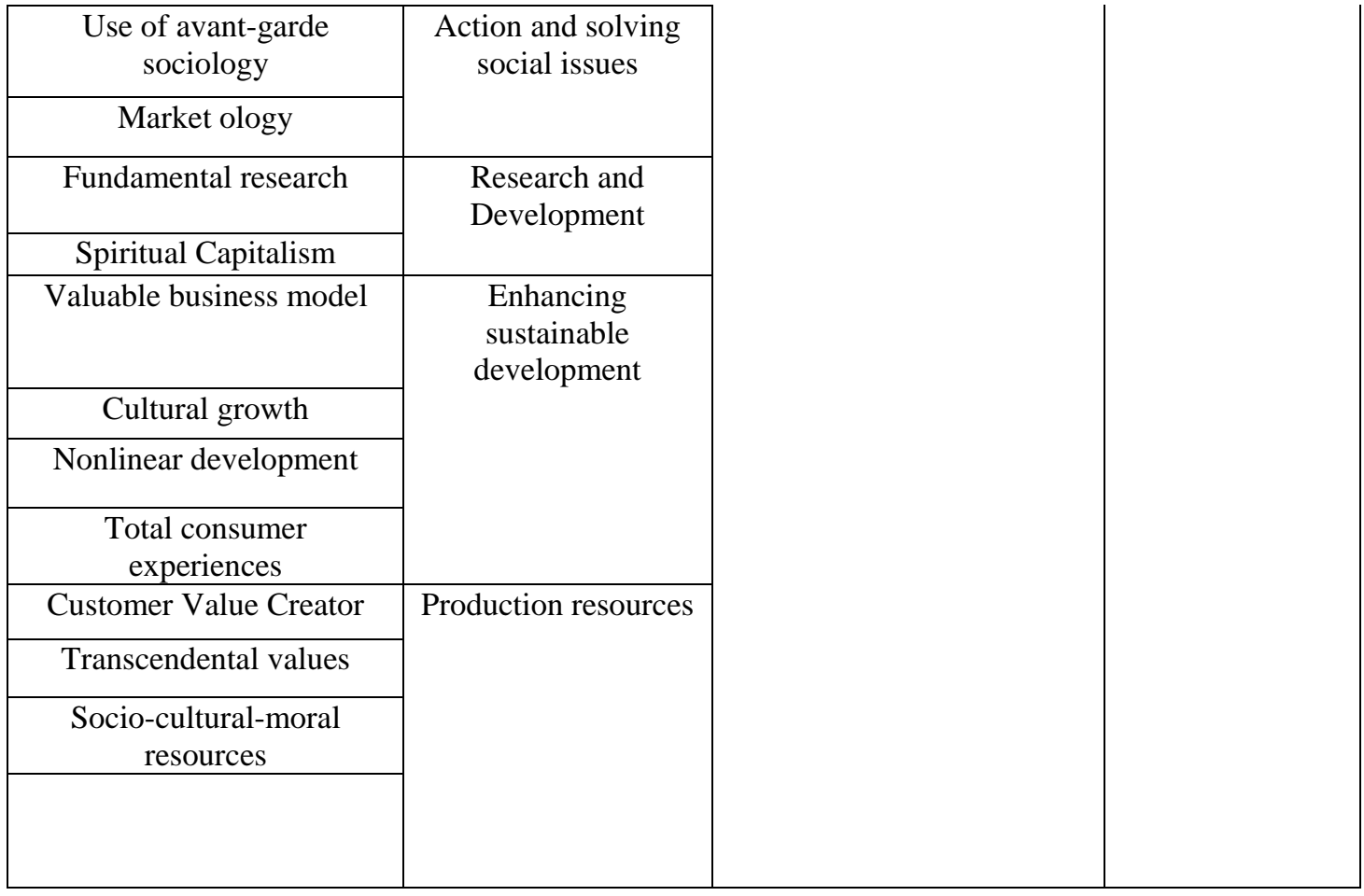

The cluster of pragmatic marketing categories includes the first level categories of "pragmatic", "problem-centered", "evolutionary product", "pragmatic marketing starter management process". Pragmatic marketing is "practical." It seeks to develop meaning of product and achieve the truth, the best way to solve the problem, in social practice, pragmatism by doing the best in a relaxing situation, and the openness of meaning in social practice leads to an increase in the positive inner attitude of customer.

Pragmatic marketing is "problem-oriented", by quickly evaluating environment, it seeks to solve social and cultural problems, and tries to offer its practical alternative for issues that require real time. A pragmatic marketing product is an "evolutionary product" that evaluates the pragmatic marketing of the product experience, assesses its social, cultural, and moral implications, receives the critics' criticizes and then improves its product philosophy, pragmatic marketing has a theoretical and practical interaction and is a product improvement from crust to core.

Pragmatic marketing has the strategic management of pragmatic marketing. The first phase is the market that includes knowledge of market issues, determination of competitive perspectives, asset valuation, recognition of competitive differentiation and analysis of loss and gain. The second phase focuses on market definition, product portfolio, product path mapping, and distribution strategy. 


\section{INDEPENDENT JOURNAL OF MANAGEMENT \& PRODUCTION (IJM\&P)}

http://www.ijmp.jor.br

v. 11, n. 6, September - October 2020

ISSN: 2236-269X

DOI: 10.14807/ijmp.v11i6.1150

The third phase is business, which includes the decision to buy, build or share resources, determine product profitability, pricing, innovation, and business plan. The fourth phase is the planning of stakeholder analysis, scenario analysis, buyer-consumer character, needs analysis and buyer's experience and positioning; the fifth phase is channel support, actions, events and programs, the sixth phase is channel training, toolkit, setting up of the sales relations, production of content; the seventh phase includes conservation and growth and income plans, operational marketing plans, implementation, development, communication and support; the eighth phase is tool development and measurement, which involves building a social platform for customer experiences and suggestions, examines their complaints as a tool for customer engagement and product improvement, as well as developing tools related to the statement, assessment and improvement of statement. The final stage is the effort for sustainable development.

\subsubsection{Field conditions}

Field conditions which involves conditions and fields affecting main phenomenon (FERASATKHAH, 2016, p. 100). Field conditions have two categories of clusters, the "age of concepts" and "communicative rationality." "The Age of Concepts" is a concept that comes from the context of present day. In his book third age, Katler says that in the current collaborative world that is influenced by the new generation of technology and connects consumers to each other, consumers have the most use of social media.

They affect entire community by their lifestyle and attitudes. Their ideas about contradiction of globalization and issues and problems of society shape opinions of others and criticize the brand that has social, economic and environmental effects on people's lives. This transfer and publication of information has created an atmosphere of dialogue among humans, which has led to development of concepts; hence, the consumer does not only consume, but also creates himself, the emergence of creative communities of its effects, most of them are innovators who create and use new technologies and concepts (KATLER, 2010). . Example of category block of field conditions is presented in Table 5.

Table5: Example of category block of field conditions
\begin{tabular}{|c|c|}
\hline Concepts & Cluster category \\
\hline Age of engagement & Age of concept \\
\hline Age of global contradictions & New wave technology \\
\hline
\end{tabular}

Its "communicative rationale" includes second level of categories, "countering fundamentalism," "role of language," "liberating efforts," and "General hermeneutics". Due to 
INDEPENDENT JOURNAL OF MANAGEMENT \& PRODUCTION (IJM\&P)

http://www.ijmp.jor.br

v. 11, n. 6, September - October 2020

ISSN: 2236-269X

DOI: 10.14807/ijmp.v11i6.1150

the increasing role of language in human life and its utilization in human communication, we can agree on common sense based on theory of truth that improves society as a product of social creation. In fact, foundations and infrastructure of concepts are foundations and infrastructure of society, in this critical space, the paradigm of instrumental rationality is weakened, and the effect of subjects goes out of focus and reaches mutual understanding. (HEIDARI, 2004).

"Confronting fundamentalism" means confronting with imposition of one’s thoughts and ideas on another, that is, the confrontation of man with the will of his power, the interconnection and coordination with others cannot proceed according to personal desires, there must be norms for regulating existing relationships to prevent people from distorting this connection and coordination. These norms are called ethics, which are effective in the light of weakening the will of truth.

According to Dragon, "liberating efforts” can be defined as humans have found a secure environment for a deeper discussion of their concepts and development by developing communications and social networks, which itself is subject to humanitarian ideals and reduces discrimination among humans, to which they refer to emancipatory thoughts (Dragon, 2012.

In social and democratic social systems, "the role of language" is more effective in formation and development of social communication; in such a society, not only the community, but also language grows and improves, and the space to critique the actions and beliefs of others and to reach inter-intellectual agreement are provided.

Habermas considers communicative rationality as an opportunity to achieve "general hermeneutics", i.e. dialectics and inter-intellectual discourse, and leads to inter-intellectual understanding on deep-seated connections of a phenomenon.

\subsubsection{Intervener conditions}

What are the field and causative factors causing the general environmental factors to be adjusted? (FERASATKHAH, 2016, p. 100). It includes three clusters of "commercial ethics", "cultural materialism" and "conceptual contradictions". "Commercial ethics" is one of the issues in the commercial space, the immoral approaches to consumption of goods are of the first category, these unethical approaches resulting from the fragmentation of welfare, the disruption of the post-modern social order, the expansion of the skepticism resulting from it which itself prevents the emergence of civilization and the creation of divisions, the emergence of nihilism due to the increasing object of life, a purely profitable relationship with the product, 
DOI: 10.14807/ijmp.v11i6.1150

a product-friendly look, the conquest of the materialist spirit and the cultural stereotype, as well as the instrumentation of moral values for profit through increasing the pleasures of behavioral tendencies, similar behavioral behaviors and routines in the minds of consumers are its characteristics.

"Cultural Materialism", whose negative ideological functions are of the third-level categories, through the use of culture industry to monitor consumer consciousness and creating a mass market, consumer pain relief reduces perceptions of pain through cultural factors such as myths, religion, rituals ... and the creation of nervous shocks, sacredness through differentiation and non-normalization of consumption, creation of fear and blind respect, subsequent neglect of inability to recall premature events, inability to memorize new information, suppression of memory by eliminating signs, distorting long-term memory and creating consumer insecurity, implicit exploitation of signs, and creating hidden cultural layers in products and practices through representations, economic infrastructure and culture superstructure and suppression of systemic and non-thinker's critics of knowing the customer, which ultimately is one of the consequences of future brand discredit.

"Conceptual contradictions" are unavoidable in the era of concepts, in the selection of material and immaterial values, when faced with the reality of cognitive conflicts in mind and action, these conflicts are not necessarily destructive, but interfering a biased view will increase their gaps and makes human cognitive heterogeneity psychologically. Examples of conflicts found in this research include conflict of cultural confrontation and cultural influence, conflict of channels of universality of values, conflict between moralism and legalism, conflict between ideal and relative values, conflict between globalization and nationalism.

\subsubsection{Phenomenon-orientedness}

We explore the central phenomenon in situ and context (FERASATKHAH, 2016, p. 100). The axial and focal category, most of which was shared by scholars and university professors, was a paradigm shift, the paradigm shift is a necessity for managing out-of-structure changes in the era of new technology and its underlying foundations. It is no longer possible to respond to the spiritual, cultural, and social needs of a purely materialist society.

Epistemologically, in order to reduce ideological conflicts, there is a need for plurality and unity of communication, and the weakening of effect of focus of subjects, so that the informed society is formed with the sustained growth of resources. A part of categorical blocks of condition-orientedness is presented in Table 6. 
ISSN : 2236-269X

DOI: 10.14807/ijmp.v11i6.1150

Table 6: Example of category blocks of condition-orientedness

\begin{tabular}{|c|c|c|}
\hline Concepts & First level category & Cluster category \\
\hline $\begin{array}{l}\text { Considering transcendental concepts and } \\
\text { wisdom }\end{array}$ & \multirow[t]{2}{*}{ Ontology Change } & \multirow[t]{18}{*}{ Paradigm shift } \\
\hline Modern metaphysical ontology & & \\
\hline Phenomenology & \multirow[t]{4}{*}{ epistemology change } & \\
\hline Hermeneutics & & \\
\hline Generic hermeneutics & & \\
\hline Generic pragmatism & & \\
\hline Developing Human civilization & \multirow[t]{6}{*}{ Consumer Growth } & \\
\hline Individual Marketing of Customers & & \\
\hline Creator customer & & \\
\hline Inability to fully control the brand & & \\
\hline Competing with consumer collective power & & \\
\hline Limitation of marketers activity & & \\
\hline Information distribution & \multirow{4}{*}{$\begin{array}{l}\text { New wave } \\
\text { technology }\end{array}$} & \\
\hline paradox of globalization & & \\
\hline Creative community & & \\
\hline Engagement era & & \\
\hline $\begin{array}{l}\text { Multiple and Contradictory Comprehensive } \\
\text { Channels }\end{array}$ & $\begin{array}{l}\text { Out of structure } \\
\text { Changes }\end{array}$ & \\
\hline Linking individual motives with morality & $\begin{array}{c}\text { Development of } \\
\text { individual spirituality }\end{array}$ & \\
\hline
\end{tabular}

\subsubsection{Strategies, actions and interactions}

What actions and tactics actors take because of causative reasons? (FERASATKHAH, 2016, p. 100). The paradigmatic shift of action leads causative reasons towards new strategies from earlier concepts, categorical block of strategies include four categorical clusters as "cultural marketing", "institutional strengthening", "spiritual marketing" and "communication compliances". A part of categorical cluster of cultural marketing is presented in Table 7.

Table 7: Sample of categorical blocks of strategies

\begin{tabular}{|c|c|c|c|c|}
\hline Concepts & $\begin{array}{l}\text { First level } \\
\text { category }\end{array}$ & $\begin{array}{c}\text { Second level } \\
\text { category }\end{array}$ & $\begin{array}{c}\text { Third level } \\
\text { category }\end{array}$ & Cluster category \\
\hline $\begin{array}{l}\text { Behavior } \\
\text { Prediction }\end{array}$ & $\begin{array}{c}\text { Creating } \\
\text { competitive } \\
\text { advantage }\end{array}$ & \multirow[t]{6}{*}{ Market ology } & & \\
\hline $\begin{array}{l}\text { Quantitative / } \\
\text { qualitative } \\
\text { information } \\
\text { gathering tools }\end{array}$ & $\begin{array}{c}\text { Quantitative / } \\
\text { qualitative } \\
\text { research method }\end{array}$ & & & \\
\hline $\begin{array}{l}\text { Consumer } \\
\text { influence }\end{array}$ & \multirow[t]{4}{*}{$\begin{array}{l}\text { Creating Social } \\
\text { Campaigns }\end{array}$} & & & \\
\hline $\begin{array}{c}\text { Identifying } \\
\text { customer needs / } \\
\text { incentives / } \\
\text { insights }\end{array}$ & & & & \\
\hline $\begin{array}{c}\text { Predicting change } \\
\text { of consumer } \\
\text { attitude }\end{array}$ & & & & \\
\hline $\begin{array}{l}\text { Psychological and } \\
\text { behavioral } \\
\text { analysis of the } \\
\text { consumer }\end{array}$ & & & & \\
\hline
\end{tabular}


ISSN: 2236-269X

DOI: 10.14807/ijmp.v11i6.1150

\begin{tabular}{|c|c|c|c|}
\hline $\begin{array}{c}\text { Improved product } \\
\text { / service / brand } \\
\text { message }\end{array}$ & & & \\
\hline Identifying trends & \multirow{4}{*}{$\begin{array}{l}\text { dynamism of } \\
\text { culture }\end{array}$} & \multirow{14}{*}{ Cultural insights } & \\
\hline $\begin{array}{c}\text { Socio-cultural } \\
\text { orientations }\end{array}$ & & & \\
\hline $\begin{array}{l}\text { Unwillingness of } \\
\text { society to change }\end{array}$ & & & \\
\hline $\begin{array}{l}\text { Probabilistic } \\
\text { Changes in } \\
\text { Community } \\
\text { Attitudes }\end{array}$ & & & \\
\hline Religion & \multirow{5}{*}{$\begin{array}{l}\text { Understanding } \\
\text { intricate cultural } \\
\text { matrix of a } \\
\text { community }\end{array}$} & & \\
\hline Values & & & \\
\hline Traditions & & & \\
\hline Social norms & & & \\
\hline $\begin{array}{l}\text { Method of } \\
\text { behaviors } \\
\text { coverage }\end{array}$ & & & \\
\hline $\begin{array}{l}\text { Advantage and } \\
\text { Competitive } \\
\text { Position of } \\
\text { Product / Brand }\end{array}$ & \multirow{5}{*}{$\begin{array}{c}\text { Combining } \\
\text { cultural insights } \\
\text { and marketing } \\
\text { strategy }\end{array}$} & & \\
\hline Future success & & & \\
\hline Change of culture & & & \\
\hline $\begin{array}{l}\text { Change of } \\
\text { consumer } \\
\text { behavior }\end{array}$ & & & \\
\hline $\begin{array}{c}\text { Change } \\
\text { movements }\end{array}$ & & & \\
\hline $\begin{array}{l}\text { Transform from } \\
\text { biological to } \\
\text { cultural being }\end{array}$ & internal marketing & \multirow[t]{8}{*}{ Education } & $\begin{array}{c}\text { Cultural } \\
\text { Marketing } \\
\text { Management } \\
\text { Process }\end{array}$ \\
\hline $\begin{array}{l}\text { Balancing work } \\
\text { and personal life }\end{array}$ & & & \\
\hline $\begin{array}{l}\text { Customer } \\
\text { engagement in } \\
\text { advertising }\end{array}$ & \multirow[t]{6}{*}{$\begin{array}{c}\text { Individual } \\
\text { empowerment }\end{array}$} & & \\
\hline $\begin{array}{c}\text { Reducing } \\
\text { Violence and } \\
\text { Fundamentalism }\end{array}$ & & & \\
\hline $\begin{array}{c}\text { Flourishing } \\
\text { individual talent in } \\
\text { practice }\end{array}$ & & & \\
\hline $\begin{array}{l}\text { Self-regulation in } \\
\text { dealing with } \\
\text { relationships }\end{array}$ & & & \\
\hline $\begin{array}{l}\text { Preceding ethics } \\
\text { on consumerism }\end{array}$ & & & \\
\hline $\begin{array}{l}\text { Improved } \\
\text { conscious } \\
\text { selection }\end{array}$ & & & \\
\hline
\end{tabular}

Cultural marketing 
ISSN: $2236-269 X$

DOI: 10.14807/ijmp.v11i6.1150

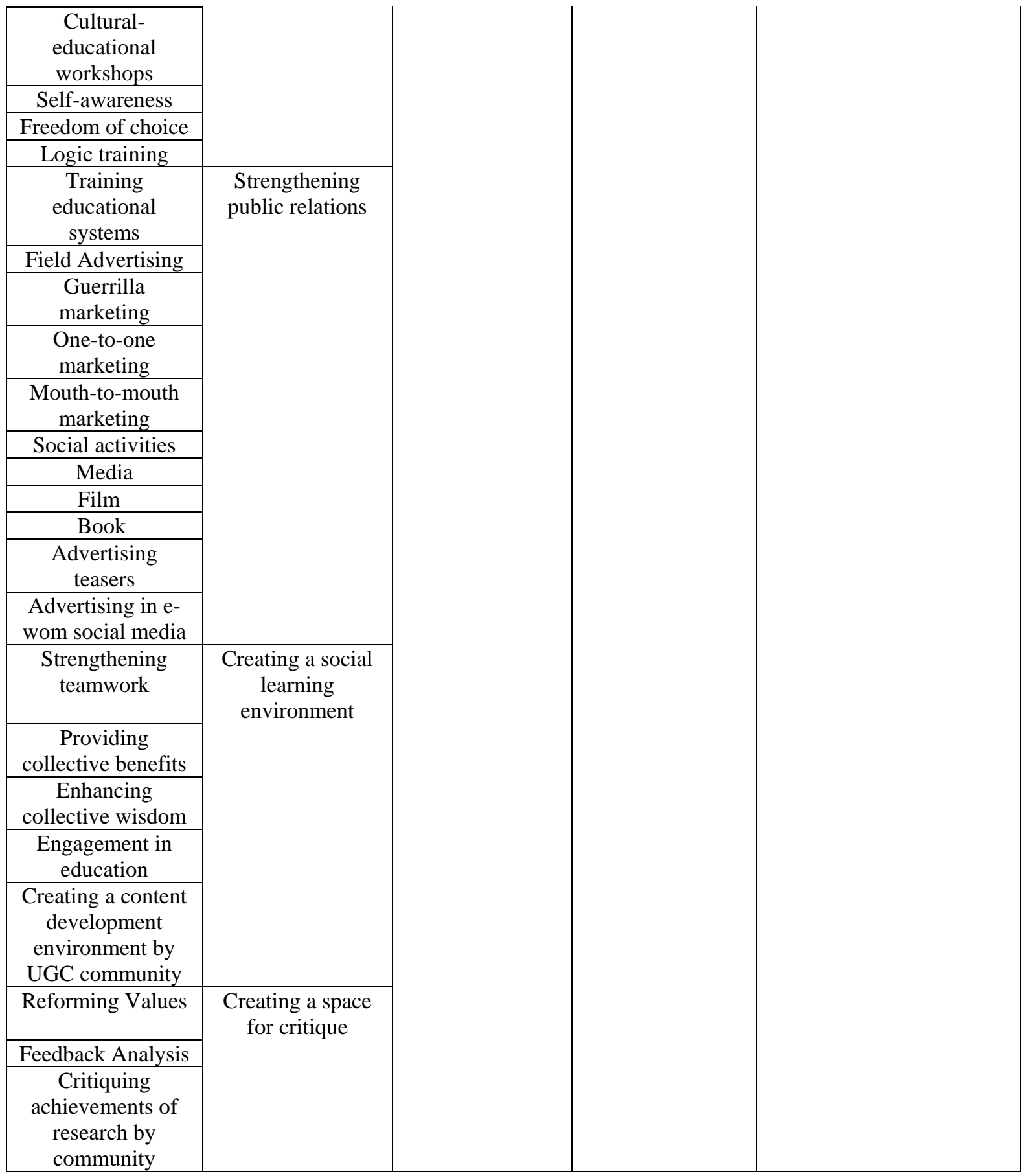

"Spiritual Marketing" is another categorical cluster of strategic block, of its third level categories of decoding the phenomena in a concrete way, of phenomenological exposure, of achieving unity and multiplicity of knowledge in the general hermeneutics method, and opening up semantics in social practice along with questioning fundamental human concepts, representation of phenomena by means of semiotics and development of meaning through language using rhythmic and terminology, deepening of concepts by creating hidden and complex layers of brand, which must take place in open space of social critique, transfer of values must be through interaction of relative and ideal values. 
INDEPENDENT JOURNAL OF MANAGEMENT \& PRODUCTION (IJM\&P)

http://www.ijmp.jor.br

v. 11, n. 6, September - October 2020

ISSN: $2236-269 X$

DOI: 10.14807/ijmp.v11i6.1150

Ratio of values is accomplished with truth and identity. Innovation is through creation of new life styles, the development of creative market, reduction of market penetration, creative social reinforcement, active workers, production of new technology and production of new concepts.

"Cultural Marketing" includes other third-level categories, such as managing cultural issues that must identify marketing areas in the age of global contradictions and presenting an alternative to high-level culture. Strengthening customer mindsets to increase customer consciousness through creation of a mind that has self-control and self-examination of environment and shows behavioral self-esteem, strengthening consumer memory through semantic encoding by meaningful links to memory, high conflict with phenomena, learning through insight to solve problems, complex learning through cognitive maps, recognition of categories by referring to memory, recognizing from signs and describing phenomenon of unstructured features, enhancing sensory systems of customer, internally and externally, to learn more about stimuli through visual complexity, resonance and animation intensity, employing product learning strategies by dividing them according to emotional and logical values; developing personal and social self-manifestations by improving emotional cognition, logical understanding and development of mental schemas and customer growth history, improving tangible and intangible beliefs of product by providing opportunities for rational and emotional cognition of product, increasing value of a cultural product by improving awareness and brand association, strengthening meaning beyond product name, receiving emotional responses from customer, as well as its ideological function, creation of a dynamic ideological system that itself has the dynamism of idea and solving conflicts with phenomena and its social function. It maintains the order of social life and dynamic interaction of civic and ecological functions, adaption of system with habitat, compatibility with technology and efficient interaction with the environment.

"Strengthening Institutions" is another category cluster of strategic bloc, changing institutions from economic to socioeconomic, meaning of collective life through civic oversight, monitoring performance of National Resource Managers, bargaining for social exclusion, strengthening social constructivism, supporting community-based organizations and social movements to reduce violence and increase community bargaining, protesting immoral situations and efforts to protect social capital, strengthening social networks by improving atmosphere of critique and exchange of ideas, strengthening of collective wisdom and desirability of individual and social life are examples of its categories. 


\section{INDEPENDENT JOURNAL OF MANAGEMENT \& PRODUCTION (IJM\&P)}

http://www.ijmp.jor.br

v. 11, n. 6, September - October 2020

ISSN: 2236-269X

DOI: 10.14807/ijmp.v11i6.1150

"Spiritual Marketing" is another category cluster of strategic blocs, of its third level categories of decoding phenomena in a concrete way, of phenomenological exposure, of achieving unity and multiplicity of knowledge in general hermeneutic method, and opening up semantics in social practice along with questioning fundamental human concepts, representation of phenomena by means of semiotics and development of meaning through language using rhythmic and terminology, deepening of concepts by creating hidden and complex layers of brand, which must take place in open space of social critique, transfer of values must be through interaction of relative and ideal values, ratio of values is done with truth and identity, innovation is through creation of new life styles, development of creative market, reduction of market penetration, creative social reinforcement, active workers, production of new technology, production of new concepts.

"Communication compliance" is another categorical cluster of strategic bloc that acts in the open space of social critique by strengthening interactions in social networks, enhancing collective wisdom, rebranding, and offering cultural, meta-regional, globalization, and addressing problem-solving alternatives, valuation indicators with a proportion of truth and taking into account distance of human ontology from phenomena, taking customer as a thinking person into account and reducing his concerns and increasing credibility of brand's future.

\subsubsection{Consequences}

What are the consequences of causal actions and strategies that are being adopted? (FERASATKHAH, 2016, p. 101). Categorical blocks of consequences includes categorical clusters of "customer engagement", "genuine leadership", "creativity", "imagery of utopia", "scarcity", "culturalism", "differentiation", "honesty", "problem-centered", " interaction with archetypes," "self-awareness," "dynamism of beliefs," "economic value," "sociality," "brand equity". The "customer engagement" cluster is presented below. Sample categorical block of consequences is presented in Table 8.

Table 8: Sample categorical block of consequences

\begin{tabular}{|c|c|c|}
\hline Concepts & First level category & Cluster category \\
\hline $\begin{array}{l}\text { Promoting the meaning of } \\
\text { customer life }\end{array}$ & \multirow{7}{*}{ customer engagement } & \multirow{7}{*}{ Authentic brand } \\
\hline Increasing customer presence & & \\
\hline Enhancing customer experience & & \\
\hline $\begin{array}{l}\text { Improving image of endless } \\
\text { customer relationship with brand }\end{array}$ & & \\
\hline Brand Perfectionism & & \\
\hline Brand Responsibility to Customer & & \\
\hline customer's honor to brand & & \\
\hline
\end{tabular}


ISSN: 2236-269X

DOI: 10.14807/ijmp.v11i6.1150

Customer support in solving problems fairly and satisfactorily

Brand equity behavior

Obligations compliance Brand Trust

The categorical cluster of " Authentic leadership," which itself includes first-class categories of risk-taking beyond profit and benefit, creativity, strategic plan, attractiveness, belief in leadership and collective wisdom, anti-populist, position leader, the will to truth, honesty, enthusiasm, identity, self-consciousness, attachment to moral values, corruptibility, the fight against corrupt systems.

Another categorical cluster is "creation", which includes the emergence of a mode of being, self-identity, appearance of self and creation of new concepts.

"Illustration of utopia" is another cluster, its categories is creating hope and motivation and transfer of human values to society through historical subjectivity. "Scarcity" means that it analyzes the situation and understands the consumer, with its own skill, offers a unique style to solve problems, since it is not initially accepted by the community and its idea is initially a claim. The ability to withstand their social pressures with resistance to dogmatism and mass market, inefficient pressures and systemic determinism as well as social tolerance, value creation in different conditions, and actors of system change.

"Being Cultural" means the importance of thinking, which involves living on the basis of human being, having a worldview and thinking about fundamental human concepts, questioning, contributing to production and growth of meaning, tradition renovation through emergence of cultural ideals and transfer of values to society.

"Distinction" is a genuine brand based on its intellectual property, "honesty" includes the truth of word, action to multitude and the trust of society, "problem-centered" to address alternative cultural-social issues and metaphysical values. "Interacting with archetypes" involves linking with archetypes and tradition and their rebranding, "self-awareness" is valued for human values, meaningfulness of suffering, pleasures, and behaviors in society.

The "dynamism of beliefs" is the avoidance of ideological prejudices and openness in the recognition of phenomena. "Economic value" includes improving the production process and trying to achieve the goal of generous production. "Sociality" includes community responsiveness, self-improvement based on social critique, respect for others, bargaining with the community, respect for the community, understanding and empathy with community, engagement in community development through engagement in solving community problems. 
ISSN: 2236-269X

DOI: 10.14807/ijmp.v11i6.1150

Increasing "special brand value" by enhancing brand awareness through brand symbols and brand image branding by developing the meaning of commercial bread and increasing perceived value and brand loyalty by getting emotional and cognitive responses on brand on special brand value.

\subsubsection{Paradigmatic model}

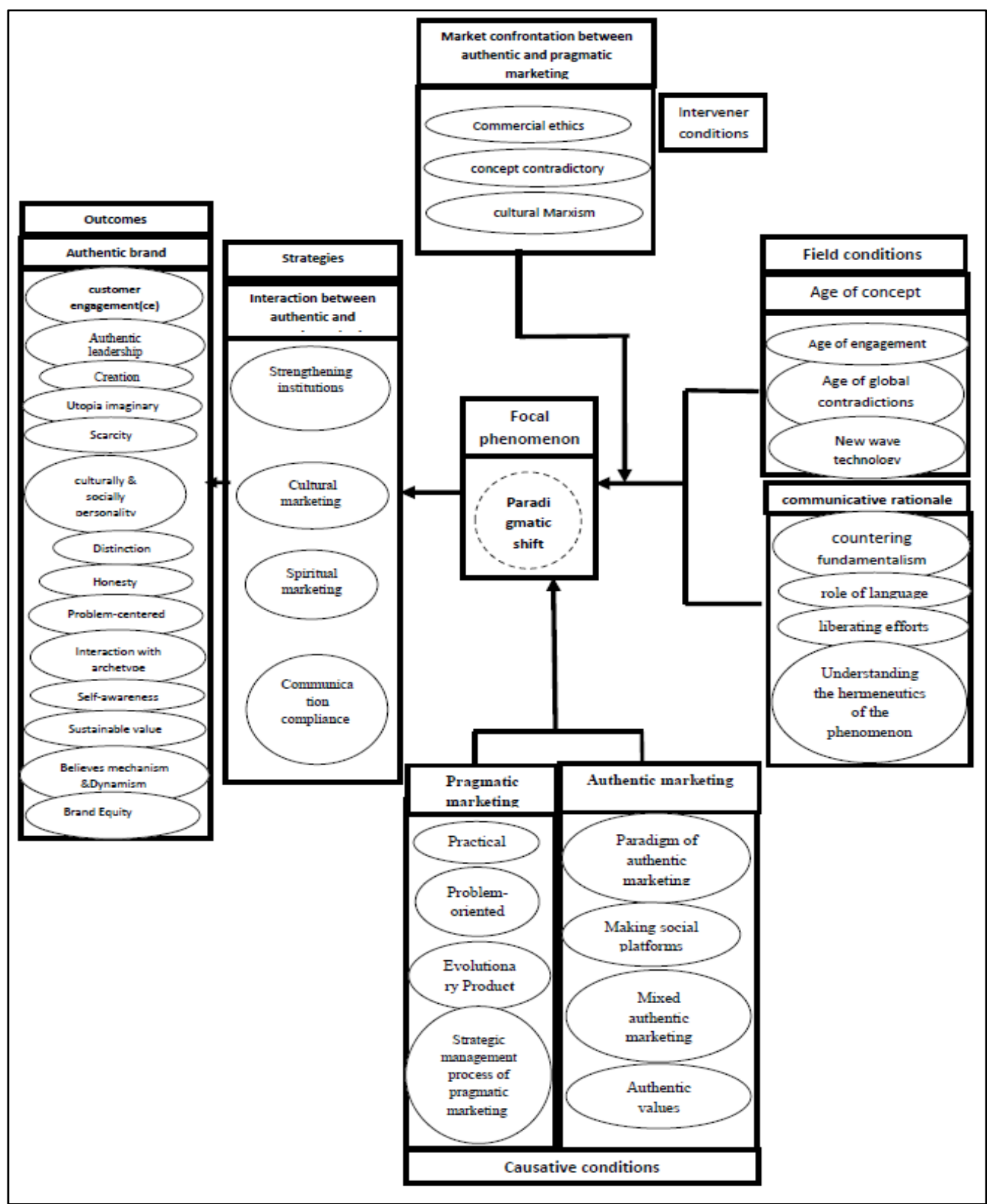

Figure 1: Paradigmatic model for Authentic Marketing, Pragmatic Marketing (Components, Foregrounds, Outcomes): Interactions \& Conflicts Source: KHEIRY; ALIESMAEILI (2019)

\section{CONCLUSIONS}


INDEPENDENT JOURNAL OF MANAGEMENT \& PRODUCTION (IJM\&P)

http://www.ijmp.jor.br

v. 11, n. 6, September - October 2020

ISSN: 2236-269X

DOI: 10.14807/ijmp.v11i6.1150

The existing fields in the present era have provided a vast amount of knowledge to mankind. Although this abundance had achievements of thinking, creativity, awareness and engagement for human beings, it transformed his previous relationship and faces it a variety of conflicts and disputes.

Although these contradictions, on the one hand, can bring a new way of knowing for man, on the other hand, the limits of conflict go from normal to higher decisions by applying prior cognitive methods and make their behaviors superficial and discredited. Given that the man of modern age is more meaningful than any age, but has less to do with it, and by knowing that it leads to the rejection of purely instrumental behaviors, it becomes a crisis of meaning in the duality of selfhood.

In this market, which, according to Katler's definition, is the fundamental concept of exchanging value in a social process and since people in their new era value their interactions and exchanges, marketing can play an important role in regulating new relationships and creating a new order. Marketing was first defined within capitalism to increase value added and capitalist interest rates, but this instrumental definition turned sales into a tool of sale, but this definition did not manage to regulate the interactions of organizations with the market for a long time.

Then marketing changed its philosophy to meet the customer's needs and then made its interactions more complex with society, so the products entered the field of culture, but the infrastructure of those efforts are economic and its superstructure is sociocultural that is called the culture industry. This approach has negative consequences, such as attribution of marketing to the tools of ideologies, the purely beneficial relationship with society, weakening of business ethics, consumer disbelief in relation to marketing as a science, and negative attitude toward marketing as a false identity tool for him to consume more.

In the present time, the dissemination of knowledge and development of communication networks, while developing customer creativity in the field of personal business, the collective bargaining power of customers, the inability of marketers to control it, leads to inefficiencies in marketing interaction. In order to achieve the goal of sustainable development, the marketing needs to provide the basis for social interactions, marketing can have a solid and sustainable interaction with a well-established social foundation.

Such values derive their credibility from collective experience and the sources of valueproducing value are stable. Therefore, findings of this study suggest the efficient exit of 
DOI: 10.14807/ijmp.v11i6.1150

marketing from out of structure changes and achieving leading solutions in solving problems of this age suggests that authentic and pragmatic marketing considered its strategies and implications, because:

Authentic marketing identifies itself as a custodian of regulating relationships with itself, society and the environment, and takes its created credits value social platforms organized from the firm, like Dow's company, whose motto is beauty, he builds social campaigns of plurality and unity of cognitions in relation to society, and strengthens the credibility of his unique self-image brand, inspired by the community.

Authentic marketing continuously enhance and stabilize its product philosophy in social platforms and through marketology. Authentic marketing moves from core to the product crust, and it usually occurs in poor societies that face the lack of meaning or in developed societies seeking to find a new meaning of human life. Authentic marketing accepts metaphysical ontology or the achievement of man to concepts of excess experience of reason.

It tracks customers' psychosocial behaviors in their social campaigns, and boosts the presence and emotional relationship of the customer through a variety of startups as well as personalization and customization of products. Marketing pragmatic is a marketing which responds to issues that require quick response, and regulates the organization's material relationships with the community.

It has strategic planning in the middle of a time period and places itself in a social critique and develops its philosophy and meaning in social practice. In other words, it seeks learning and authenticity in action, the pragmatic marketing movement is from shell to the core of product.

New age contexts and interaction of two markets focus on the pivotal phenomenon of changing the paradigm that can we answer the informed customer with the same ontology and epistemology or logic and arrange the conflicts of the era? Marketing requires another kind of ontology that responds to customer's psychological responses and requires epistemological multiplicity and epistemological unity with the customer in epistemology.

A customer whose collective communication is not developed or does not accept the knowledge represents only one subject, or if he accepts the contradiction of the variety and diversity of channels of comprehensiveness and changes outside his structure, there is only one way for subjects and retaining its moderation and reaching out to communication perceptions 
INDEPENDENT JOURNAL OF MANAGEMENT \& PRODUCTION (IJM\&P)

http://www.ijmp.jor.br

v. 11, n. 6, September - October 2020

ISSN: 2236-269X

DOI: 10.14807/ijmp.v11i6.1150

on social platforms. Marketing therefore needs to underpin the foundation of its movement so that economics and culture will emerge on its foundations.

The use of authentic and pragmatic marketing creates strategies for organizations, such as communication perceptions that make conceptual contradictions derived from age of concepts beneficial to plurality and unity of collective wisdom in the context of continuous critique and improvement. It is also based on the strategies of institutions' rejection towards socio-economic, strengthening, organizing collective wisdom and the emergence of civilization.

Another strategy that is very applicable in the new era is cultural marketing, the difference between this cultural marketing and its previous function in the dynamism of beliefs, which redefines itself in social platforms and customer experience. Also, community education, empowerment of individuals, and the development of memory and customer schemas, transforms customer cultural marketing from biological inventory to cultural and actuarial assets.

Another useful strategy in the present age is the spiritual marketing, which improves the meaning of life in society. Meaning not means the reason for being alive, but also the exploration of truth by creating hidden and complex layers in the product, the process of decoding and codifying and representing it in interaction with customer. The consequence of these strategies is to produce an authentic brand. In other words, it enhances the brand's authentic and credible behaviors in the community and in the process of conflict with its issues, thus adding to the involvement and presence of customer in relation to itself.

The original brand is evaluated by the features that occur in the process of authentic and pragmatic marketing interaction, such as genuine leadership, which itself includes risks such as risks beyond profit, non-corruption, confrontation with corrupt systems, attachment to moral values, etc. , as well as generating economic values and moving towards abundance, illustrating utopia, and motivating and transferring values to society, self-awareness as preeminence of human values to transient profits and action in accordance with conditions, socialization, association with archetypes, scarcity that reflects its talent in tolerating social pressures and social tolerance, it presents alternative social problems and other features of research findings, with production of authentic brand marketing, can play a role in regulating relations and making another order in accordance with contexts of new age which have an efficient role and presents independent theories from instrumental view. 
DOI: 10.14807/ijmp.v11i6.1150

Limitation Due to social, structural, research problems in the country in the past year (2018) research in qualitative interviews with professors and elites, in order to achieve theoretical saturation of secondary data of lecturer files and elites in areas different books and articles, their books were used too.

\section{SOME SUGGESTION FOR FUTURE RESEARCH:}

- Since the present study investigates the effect of paradigm shift by considering the contexts of the era of concepts and communication rationality on brand authenticity, it is suggested that in future research in addition to these fields simultaneously by the fields of instrumental rationality, the system Of modernity, capitalist systems to be measured by meta-paradigm on brand authenticity.

- It is suggested that future research using the model presented in the qualitative phase of the present study measure the extent of authentic brand fulfillment among different consumer groups.

- It is suggested in future research to evaluate the impact of interventionist factors such as conspiracy theory on brand authenticity.

- It is suggested that in future research the above model be compared between different social classes and lifestyles and the results will be compared.

- It is suggested that future research into other genuine brand instances be identified through in-depth interviews with consumers and other influential social groups on the purchase decision.

- The present study has also provided an initial framework for the genuine brand and it is therefore suggested that future research should prioritize each of the identified dimensions according to the specific circumstances of the country.

- It is suggested that in future research the relationships between each dimension of the interaction structure and the contrast between the original and the pragmatic marketing will also be examined.

- It is recommended that further research be conducted on the factors that lead to the interaction and interaction of authentic and pragmatic marketing.

\section{REFERENCES}


ABAZARI, Y.; SHARIATI, S.; FARAJI, M. (2011) The Transcendence of Civilization or the Process of Civilizations?. A Reading of culture-civilization problematic. Quarterly Journal of Cultural Research, v. 4, n. 2, p. 19.

ABBAS, M. (2007) Approach and Methods in Political Science. Tehran, SAMT Publications.

AKBARI, M. H. (2006) Democracy and Civil Society. Journal of Social Sciences, n. 7.

ARANI, A. A.; NAJMEH, Z. M.; AZAD, F. M. (2016) Comparative Study of Critical Education from the Viewpoint of Girou and Habermas. Journal of Axiology in Education, n. 1.

ARNOULD, E. J.; PRICE, L. L. (2000) Authenticating acts and authoritative performances. Questing for self and community. In S. Ratneshwar, D. G. Mick \& C. Huffman (Eds.p. the why of consumption.

AZHAR, V. (2019) The Role Of Marketing Mix And Service Quality On Tourist Satisfaction And Loyalty At Samosir, Independent Journal Of Management \& Production (IJM\&Pp. v. 10, n. 5.

BARRETT-LENNARD, G. T. (1998) Carl Rogers' helping system: Journey and substance. London: Sage.

BEVERLAND, M. B.; LINDGREEN, A.; VINK, M. W. (2008) Projecting Authenticity through Advertising - Consumer Judgments of Advertisers' Claims, Journal of Advertising, v. 37, n. 1, p. 5-15.

BEVERLAND, M. B.; FARRELLY, F. J. (2010) The quest for authenticity in consumption: Consumers 'purposive choice of authentic cues to shape experienced outcomes. Journal of Consumer Research, v. 36, n. 5, p. 838-850.

BEVERLAND, M. B.; LINDGREEN, A.; VINK, M. W. (2008) Projecting authenticity through advertising. Journal of Advertising, v. 37, n. 1, p. 5-15.

BELL, J.; BROWN, S. (1990) Pragmatic Perspectives in International Marketing Education. Journal of Management Development, v. 9, n. 1, p. 39 - 50

BORGES, M. V. (2015) An Evaluation OF Supply Chain Management In A Global Perspective, Independent Journal Of Management \& Production (IJM\&P), v. 6, n. 1.

BOUTANG, Y. (2011) Cognitive Capitalism. Business \& Economics - 240 pages. Contemporary perspectives on consumer motives, goals and desires (p. 140-163) London: Routledge.

CAPPANNELLI, G. (2004) Authenticity: Simple Strategies for Greater Meaning and Purpose at Work and at Home. Clerisy Press, Emmis Books.

DAVIS, J. L. (2017) Accomplishing authenticity in a labor-exposing space. Elsevier Ltd. All rights reserved.

DELARAM, A. (2013) The issue of value creation for customer, Bank Ayandeh Bulletin, n. 2.

DOUGLAS. R. A. (1999) Business ethics and the pragmatic attitude. A Companion to Business Ethics Edited by Robert E. Frederick, Blackwell: Publishers Ltd.

DRAGON, R. (2012) Social marketing improve your social media processes and get your customer to stay forever, eBook. 
EGGERS, F.; O`DWYER, M.; KRAUS, S.; VALLASTER, C.; GÜLDENBERG, S. (2013) The impact of brand authenticity on brand trust and SME growth: A CEO perspective, Journal of World Business, v. 48, n. 3, p. 340-348.

FADHILA, D. (2018) Authenticity and Transparency in Influencer Instagram Content in Indonesia. Bachelor's Thesis, International Business.

FARHANGI, A. A.; KARROUBI, M.; FARAZ, S. V. (2015) classic data-based theory, description of stages of theory of center gravity identity.

FLORIDA, R. (2005) The Flight of the Creative Class: The New Global Competition for Talent . New York: HarpermBusiness.

FROSH, P. (2001) To thine own self be true: The discourse of authenticity in mass cultural production. The Communication Review, v. 4, p. 541-557.

GHOLIPOUR, H. (2007) From Weber to Habermas about Science and Values. Robert Hollinger, Humanities Psychology Magazine, n. 48.

GILMORE, J. H.; PINE, B. J. (2007) Authenticity: What consumers really want?. Boston: Harvard Business School Press.

GRAYSON, K.; SCHULMAN, D. (2000) Indexicality and the verification function of irreplaceable possessions: A semiotic analysis. Journal of Consumer Research, v. 27, p. 1730.

GROHMANN, B. (2009) Gender dimensions of brand personality. Journal of Marketing Research, v. 46, n. 1, p. 105-119.

GUEVREMON, A.; GROHMANN, B. (2016) The brand authenticity effect: situational and individual-level moderators. European Journal of Marketing, v. 50, n. 3/4.

HABERMAS, J. (1987) The Theory of Communicative Action. Translated by T. McCarthy. Boston: Beacon Press, v. 1 and 2.

HAGHIGHI, M.; KARAMI, M.; ELIYA, B. Z. (2013) Customer's Trust to Large Store Personnel: A study in chain store clients. Study in Chain stores in Shahrvand Tehran, Management Sciences Association, v. 8, n. 3.

HAKIMI, M. (1984) Compilation and editing by Mahmoud Hakimi. Subject: History; Quotes. Ghalam Publishing, Tehran, 1984. Iran Health Branding. Commercial Management Quarterly, v. 7, n. 1, p. 145-162.

HANDY, C. (1994) The age of Paradox. Boston:Harvard Business school business School Press.

HANDLER, R.; SAXTON W. (1988) Dyssimulation: Reflexivity, narrative, and the quest for authenticity in -living history. Cultural Anthropology, v. 3, n. 3, p. 242-260.

HANNES K.; STAES F.; GOEDHUYS J.; AERTGEERTS B. (2009) Obstacles to the implementation of evidence-based physiotherapy in practice: a focus group-based study in Belgium (Flanders) Physiotherapy: Theory and Practice, v. 25, n. 7, p. 476-488.

HATAMINEZHAD, H.; AKBARPOUR, S. M. (2011) Pragmatism. Journal of Geographic Information, n. 79.

HE, M.; LI, J.; SHAO, B.; QIN, T.; REN, C. H. (2013) Transforming massive data to pragmatic target marketing practice. IBM Research - China. 
HEIDARI, H. H. (2004) Habermas in the battle with modern epistemic crisis, communicative rationality instead of instrumental rationality. Institute for Humanities and Cultural Studies, n. 33.

HOLT, D. B. (2002) Why Do Brands Cause Trouble?. A Dialectical Theory of Consumer Culture and Branding, Journal of Consumer Research, v. 29, n. 1, p. 70-90.

HOLT, D. B. (2004) How brands become icons: The principles of cultural branding. Boston: Harvard Business School Press.

HOSSEIN, M. M. (2015) Value-based sociology by relying on order and security. Tehran, Military science university, Second Edition.

HUNT, S. D. (2013) The Basics of Theorizing in Marketing. Mohammad Haghighi and Masoud Karami, Tehran, Krtab Mehraban Publishing Institute.

ILICIC, J. M.; WEBSTER, C. (2014) Eclipsing: When Celebrities Overshadow the Brand, psychology marketing, p. 1040-1050.

INGLEHART, R.; PIPPA, N. (1999) Rising Tide: Gender Equality and Cultural Change around the World. Cambridge: CambridgeUniversity Press.

ISORAITE, M. (2014) Raising Brand Awareness Through The Internet, Marketing tools, Independent Journal Of Management \& Production (IJM\&P), v. 7, n. 2.

JEANNERAT H. (2013) Staging experience, valuing authenticity: Towards a market perspective on territorial development, Published in European Urban and Regional Studies, v. 20, n. 4, 370-384.

KHAKI, G. R. (2011) Research Method with a Thesis Approach. Tehran: Baztab Publication.

KATLER, F. (2015) Third Generation Marketing. Translated by Hormoz Mehran and Behzad Shahrabi, Reza, Cultural Services Institute Publishing.

KOLAR, T.; ZABKAR,V. (2010) A consumer-based model of authenticity: An oxymoron or the foundation of cultural heritage marketing?, Tourism Management, v. 31, p. 652-664.

KOTLER, P.; KARTAJAYA, H.; SETIAWAN, I. (2010) Marketing 3.0: From Products to Customers to the Human Spirit. Publisher, John Wiley \& Sons.

LEIGH, T. W.; PETERS, C.; SHELTON, J. (2006) The consumer quest for authenticity: the multiplicity of meanings within the MG subculture of consumption. Journal of the Academy of Marketing Science, v. 34, n. 4, p. 481-493.

MAHJOO, M. (1986) Perspective of the Iranian Economy. Iran Steel news station.

MIRJALILI, S. H. (2002) The Study of the Economic, Political, Social and Cultural

Structure. Research Institute for Humanities and Cultural Studies, n. 270.

MOHAMMADPOUR, A. (2013) Qualitative Research Method for Handling 1. Tehran: Jameeshenasan Publications.

MORHART, F.; MALAR, L.; GUEVREMONT, A.; GIRARDIN, F.; GROHMANN, B. (2015) Brand authenticity: An integrative framework and measurement scale, Journal of Consumer Psychology, v. 25, No. 2, p. 200-218.

MOULAERT, F.; SEKIA, F. (2003) Territorial innovation models: a critical survey. Regional Studies, v. 37, p. 289-302. 
MOULARD, J.; GARRITY, C.; RICE, D. (2015) What Makes a Human Brand Authentic? Identifying the Antecedents of Celebrity Authenticity. Psychology and Marketing, v. 32, n. 2, p. 173-186.

NAPOLI, J.; DICKINSON, S. J.; BEVERLAND, M. B.; FARRELLY, F. (2014) Measuring consumerbased brand authenticity. Journal of Business Research, v. 67, n. 6, p. 1090-1098.

OXFORD ENGLISH DICTIONARY. (2019) Prepared by Leeder, K. Oxford, UK: Oxford University Press.

PEIRCE, C. S. (1893) Collected Papers of Charles Sanders Peirce, v. V and VI. Edited by C. Hartshorne and P. Weiss. Cambridge: Harvard University Press.

HOLLINGER, R. (2006) From Weber to Habermas about Science and Values.

Translated by Gholipour, Hussein, Tehran, Social Sciences: Methodology of Humanities, n. 48 (ISC)

HOSSEIN, R. (2007) Organization and Management Theories: From Modernity to Renaissance Postures, v. II post-modernism era, Tehran, Douran Publishing.

REISINGER, Y.; STEINER, C. J. (2006) Re conceptualizing object authenticity. Annals to Tourism Research, v. 33, n. 1, p. 65-86.

RORTY, R. (1996) Fraternity: The case for a society based not on rights but on unselfishness. New York Times Magazine, September 29, p. 155-8.

ROTFELD H. J. (2014) The pragmatic importance of theory for marketing practice. Journal of Consumer Marketing, v. 31, n. 4, p. 322-327.

SAEED, A. E.; ARASH, H. N.; MOJTABA, N. A. (2012) Business Ethics: The Inevitable Needs of Trade Organizations, Opportunity Quarterly, n. 2.

SALVADOR, R.; FRANCISCO, A.; PIEKARSKI, C.; LUZ, L. (2014) Life Cycle Assessment (LCA) As A Tool For Business Strategy, Marketing tools, Independent Journal Of Management \& Production (IJM\&P), v. 5, n. 3.

SCHMIDT, S.; HENNIGS, N.; ALBERTSEN, L.; KARAMPOURNIOTI, E.; ROTHENSEE, M. A. (2017) The Dual Information Processing Effect of Pragmatic and Hedonic User Experience on Brand.

SHETH, J. N.; SISODIA, R. S. (2006) Does Marketing Need Reform? Fresh Perspectives on the Future. USA, M.E. Sharpe Inc.

SHIROUDI, M. (2009) The study and methodology of political science. Journal of Religion and Politics, n. 19-20. work and at Home", Clerisy Press, Emmis Books.

TAVASOLI, G. A.; MARZIEH, M. (2005) The concept of capital in new and classical theories with an emphasis on social capital theories. Journal of Social Sciences, n. 26.

THOMPSON, C. J. (1997) Interpreting Consumers: A Hermeneutical Framework for Deriving Marketing Insights from the Texts of Consumers' Consumption Stories. Journal of Marketing Research, v. 34, p. 438-5.

WALDO, E. R. (2007) The Letters of Ralph Waldo Emerson. Ed. RALPH, L.; RUSK, v. 1_6; TILDEN, E. M., v. 7_10. New York and London: Columbia University Press.

WHITE, T, J. (1990) Amplification and direct sequencing of fungal ribosomal RNA

Genes for phylogenetics, Publisher: Academic Press, p. 315-322. 
DOI: 10.14807/ijmp.v11i6.1150

ZADEH, F. H.; ABDOLMALAKI, J. (2013) Proposal writing in Qualitative and Combined Studies, Tehran: Jameshenasan Publishing.

ZICKMUND, S. (2007) Deliberation, phronesis and authenticity: Heidegger's early conception of rhetoric. Philosophy \& Rhetoric, v. 40, n. 4, p. 406-415.

ZOHAR, D.; IAN, M. (2004) Spiritual Capital: Wealth We Can Live By: (San Francisco: Barrett_Koehler Publisher. 